\title{
Hull Form Factor Prediction of Mini Submarine Model Using Prohaska Method
}

\author{
Mahendra Indiaryanto ${ }^{\mathrm{a}}$, Ahmad Syafi'ul Mujahid ${ }^{\mathrm{b}, *}$, Taufiq A Setyanto ${ }^{\mathrm{c}}$, Navik Puryantini ${ }^{\mathrm{d}}$ \\ andonesian Hydrodynamics Laboratory, Agency for the Assessment and Application of Technology (BPPT) Indonesia. \\ Email: indiaryanto@gmail.com \\ ${ }^{b}$ Indonesian Hydrodynamics Laboratory, Agency for the Assessment and Application of Technology (BPPT) Indonesia. \\ Email: aaf2k31i@gmail.com \\ ${ }^{\mathrm{c} I n d o n e s i a n}$ Hydrodynamics Laboratory, Agency for the Assessment and Application of Technology (BPPT) Indonesia \\ Email: taufiq.setyanto@gmail.com \\ ${ }^{\mathrm{d}}$ Indonesian Hydrodynamics Laboratory, Agency for the Assessment and Application of Technology (BPPT) Indonesia \\ Email: navik.puryantini@gmail.com
}

\begin{abstract}
The resistance on mini-submarines is certainly different from the type of surface vessels in general. This is related to differences in the shape of the sub's hull when compared to the surface ship. In addition to the differences in the shape of the hull, the operational area of the ship is also different, where the submarine's hull operates at full water depth, while the surface ship hull partly operates at sea level. If the submarine model is tested then the value of the coefficient of resistance will be very different. Where the component of the coefficient of resistance (CT) consists of the coefficient of friction $(\mathrm{CF})$, form factor $(1+\mathrm{K})$, and correlate allowance $(\mathrm{CA})$. Because the hull shape is different from the surface ship, then the hull form factor coefficient is the focus of this study. The prediction of the hull form factor can be searched by using Prohaska method. This method is implemented using a mini-submarine model test. Using the known value of the hull form factor, then it can be used to find the value of the coefficient of resistance and the resistance of the ship can be obtained.
\end{abstract}

Keywords: Hull form factor; Prohaska method; resistance coefficient

\section{Introduction}

In the past decade, the Agency for Assessment and Application Technology (BPPT) as one of the State research institutions has conducted several studies on submarines. Surely the design of this submarine hull matches the geographical conditions of Indonesia which is an archipelagic country and has many straits. Indirectly with many straits in Indonesia, submarine hulls are needed to operate in shallow water.

So based on these considerations, a submarine hull design with an efficient and suitable form to operate in Indonesian waters is chosen. Based on several literature studies that studied both the area of operation and the capability of cruising mini-submarines, it was decided to design the submarine hull with a length of $22 \mathrm{~m}$.

Based on these considerations then Laboratory for Hydrodynamics Technology (BTH) - BPPT tried to design a $22 \mathrm{~m}$ mini-submarine hull for its research in 2014 because the main task and function of BTH is research in hydrodynamics, submarine hull design must meet the hydrodynamic aspects, especially on the efficiency of the resistance value of the mini-submarine hull to be designed. Because an efficient resistance value

${ }^{\star}$ Corresponding author. Tel.: +6285655617011

Jalan Hidrodinamika, Gd. BPPT, Komplek ITS

Surabaya 60112 will reduce Brake Horse Power (BHP) which will be installed into a $22 \mathrm{~m}$ mini-submarine.

Some researchers have conducted studies on submarine characteristics and hull form factor, that are: Dhana [1] studied about hull form factor analysis that obtained difference of result value between ship and model hydrostatics data must be less than $2 \%$ in order both of them have not different characteristic significantly. Kusuma [2] has studied the powering calculation especially resistance calculation of the submarine using the MIT method and sister ship for calculating the Admiral coefficient. Syafiul [3] has studied the analysis of the effect of speed changes on one component of the submarine resistance force using computational fluid dynamics. Nugroho [4] studied the characteristics of the submarine hull against the fluctuate of hydrodynamics pressure dives from the ocean surface to a depth of operational and back to the surface again causing the submarine to change the burden of recurrent (repeated load) which contribute substantially to the structure of the submarine hull. Adin [5] studied the characteristics of the fluid along with the resistance components upon the ship, the scaling of the ship was used for model testing. The model of the ship that was in a 3-dimensional object was determined to find out the form factor, the value of the resistance. To estimate the 
value of form factor $(1+\mathrm{k})$, experimental ship model at low speeds less than 0.2 Froude number obtained to collect data so that the wave resistance $(\mathrm{CW})$ can be assumed to be zero.

\section{Basic Theory}

The design of surface ship hulls in general and submarine hulls are very different, the characteristics of the resistances between surface and submarines are also very different. Based on references from the book Submarine Hydrodynamic by Martin Renilson [6], a very basic distinction between the surface ship resistance and the submarine is in the wave resistance. Where on the surface ship obtained wave resistance, while submarines in diving conditions do not obtain wave resistance. Some number of resistance components while the submarine is sinking are as follows:

- Surface friction between fluid and hull occurs in all wet surface areas and the length of submarines.

- The frictional force of the fluid with some forms of foil on the wing and submarine rudder causes flow differences due to the shape of the foil itself.

- Drag resistance from the blunt shape of the front of the submarine hull.

- Induced drag is produced by the submarine hull component which produces lift for the capability of heaving and pitching movements.

From all of the resistance components described above then it is not necessary to be entirely modeled in an experiment, but just approaching by a mini-submarine hull model test at the BTH-BPPT Towing Tank facility. By testing the model, it needs to found some coefficient of resistance for the extrapolation process from the resistance value of the submarine model to the actual resistance value of the submarine by using the International Towing Tank Conference (ITTC) method.

The coefficient that needs to be sought is the value of the coefficient of resistance (CT). Where the resistance coefficient equation can be explained as follows [7]:

$$
\begin{gathered}
C T=C T m-(1+k) \cdot(C F s-C F m) \cdot C A \\
C F s=\frac{0.075}{(\log 10 R n-2)^{2}} \\
C A=0.006(L w l+100)^{-0.16}-0.00205 \\
C T m=\frac{R T m \cdot 9,81}{0,5 \rho S V^{2}}
\end{gathered}
$$

$$
\begin{array}{ll}
R n & =\text { Reynold Number } \\
L W L & =\text { Length of ship's waterline }(\mathrm{m}) \\
R T m & =\text { Model resistance value }(\mathrm{kg}) \\
\rho & =\text { Water density }\left(\mathrm{Kg} / \mathrm{m}^{3}\right) \\
S & =\text { Wetted surface area }\left(\mathrm{m}^{2}\right) \\
V & =\text { Ship speed }(\mathrm{m} / \mathrm{s})
\end{array}
$$

From some of the coefficients above, the hull form factor is very influential in calculating the coefficient of resistance. Because the shape of a mini-submarine hull is very different from surface ship type.

The most famous empirical formula to determine the form factor value is by using the Watanabe formula [8]. To find out the approach of Form factor values can also be calculated using equations from Holtrop, $1+\mathrm{k}$ ) value at the graphic in Fig. 1 can be calculated by using the least-square method [9]:

$$
1+k=1+k_{1}\left[1+k_{2}-\left(1+k_{1}\right)\right] \frac{\text { Sapp }}{\text { Stot }}
$$

where

$$
\begin{aligned}
& 1+K_{1}=\text { Form factor bare hull } \\
& 1+K_{2}=\text { Form factor appendages } \\
& \text { Sapp }=\text { Ship appendages area }\left(\mathrm{m}^{2}\right) \\
& \text { Stot }=\text { Ship wetted surface area }\left(\mathrm{m}^{2}\right)
\end{aligned}
$$

The explanation of equations $1+K_{1}$ and $1+K_{2}$ can be seen in the book Principle Naval Architecture Vol. 2 [11]. Meanwhile, to find the hull form factor on a minisubmarine, the equation above cannot be used, and the prediction value of the hull form factor is much different from the data in Table 1. To find out the value of the hull form factor and the resistance value of the model, model testing is needed. To find out the value of the minisubmarine hull form factor, the Prohaska method can be used. This method is based on ship model testing, where a mini-submarine model is towed in a towing tank at the Laboratory for Hydrodynamics Technology (BTH) by the value of Froude Number (Fn) below 0.2.

Table 1. Form factor approach of surface ships [10]

\begin{tabular}{ccc}
\hline $\mathbf{L} / \mathbf{V}^{\mathbf{1} / 3}$ & $\begin{array}{c}\text { Monohull } \\
(\mathbf{1}+\boldsymbol{k})\end{array}$ & $\begin{array}{c}\text { Catamarans } \\
(\mathbf{1}+\mathbf{b} \boldsymbol{k})\end{array}$ \\
\hline 6.3 & 1.35 & 1.48 \\
7.4 & 1.21 & 1.33 \\
8.5 & 1.17 & 1.29 \\
9.5 & 1.13 & 1.24 \\
\hline
\end{tabular}

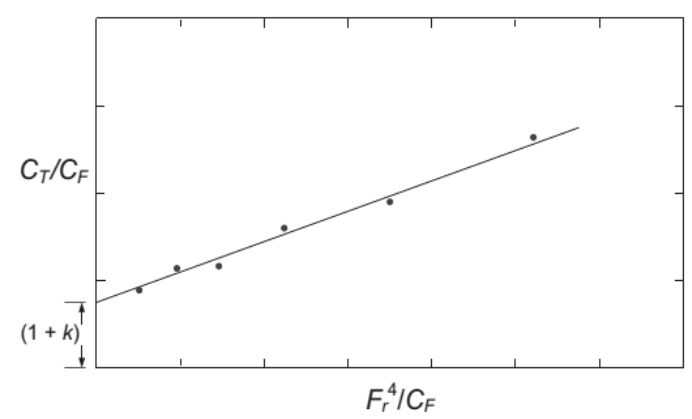

Figure 1. Form factor $(1+k)$ using the Prohaska method 
In Fig. 1, it can be seen that the Y-axis on the graph of the Prohaska method is a $C T m / C F M$ coefficient comparison, while on the $\mathrm{X}$-axis is the $F n 4 / C F m$ coefficient ratio. To find the value of Froude Number (Fn) the equation below can be used [12].

$$
F r=\frac{V}{\sqrt{L w l \cdot g}}
$$

where

Fn $\quad$ Froud number

$V \quad=$ Ship speed $(\mathrm{m} / \mathrm{s})$

$L w l \quad=$ Length of ship's waterline $(\mathrm{m})$

$g \quad=$ Gravity acceleration $\left(9.81 \mathrm{~m} / \mathrm{s}^{2}\right)$

\section{Methods}

Data and design of mini-submarine hull shapes are shown in Table 2 and Fig. 2. Furthermore, preparations for testing mini-submarine models in Towing Tank facilities are carried out such as setting up instrumentation tools and mechanical equipment on submarines. To obtain the CTm and CFM coefficients then submarine model testing is required to obtain the resistance value at Froude Number (Fn) below 0.2 [10]. Measurement of the resistance in the submarine model is conducted by measuring the total of the resistance component (Rtm) by using a load cell transducer which is installed in-line with the centerline of the ship [13]. Before testing the resistance, measurement of the water temperature at the towing tank pool is aimed to determine the level of water viscosity in the pool expressed in kinematic viscosity. For submarine speed variations, it is shown in Table 3 and the process of testing a $22 \mathrm{~m}$ minisubmarine model is shown in Fig. 3.

\section{Result and Discussion}

From the measurement of the water temperature at the towing tank pool before testing the submarine model is obtained a temperature of $28^{\circ} \mathrm{C}$. The viscosity kinematic value is $0.83572 \times 10^{-6} \mathrm{~m}^{2} / \mathrm{sec}$ at $28^{\circ} \mathrm{C}$. So the Reynold Number $(\mathrm{Rn})$ value on each variation of the ship speed can be calculated.

Table 2. The main dimension of the $22 \mathrm{~m}$ mini-submarine model with scale 1:7 [11]

\begin{tabular}{cccc}
\hline Parameter & Full Scale & Scale & Unit \\
\hline Lwl & 22 & 3.143 & $\mathrm{~m}$ \\
D total & 5.133 & 0.733 & $\mathrm{~m}$ \\
D press hull & 3.000 & 0.428 & $\mathrm{~m}$ \\
Vol $\Delta$ & 113.8 & 0.331 & $\mathrm{~m}^{3}$ \\
$S$ & 151.4 & 3.089 & $\mathrm{~m}^{2}$ \\
\hline
\end{tabular}

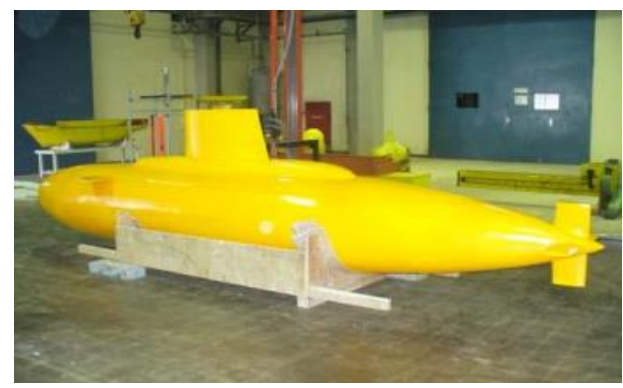

Figure 2. Model of a 22m mini-submarine with scale 1: 7
Table 3. Test speed variation of mini-submarine models with scale $1: 7$

\begin{tabular}{cccc}
\hline $\boldsymbol{V} \boldsymbol{V}$ & $\boldsymbol{V m}$ & $\boldsymbol{F n}$ & $\boldsymbol{R T m}$ \\
\hline Knots & $(\mathrm{m} / \mathrm{s})$ & & $\mathrm{Kg}$ \\
2.5 & 0.468 & 0.091 & - \\
3.0 & 0.583 & 0.109 & - \\
3.5 & 0.681 & 0.127 & - \\
4.0 & 0.778 & 0.145 & - \\
4.5 & 0.875 & 0.164 & - \\
5.0 & 0.972 & 0.182 & - \\
\hline
\end{tabular}

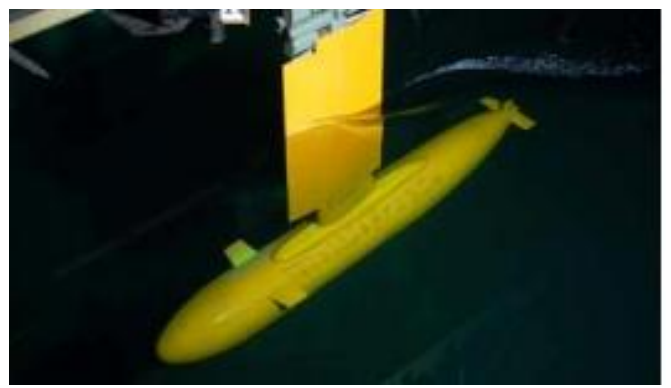

Figure 3. Testing process of the $22 \mathrm{~m}$ mini-submarine model with scale $1: 7$

The mini-submarine model testing is carried out on the mini-submarine model which is submerged approximately $1 \mathrm{~m}$ from the water surface of the pool as shown in Fig. 3. By using the speed variation data in Table 3, resistance testing is carried out to find the value of the total resistance $(R T m)$ of the mini-submarine model. From the resistance testing, the resistance graph of the mini-submarine model tends to increase significantly on each speed variation as shown in Fig. 4. This is considered reasonable because the resistance testing of the mini-submarine model measures the entire area of mini-submarine components consisting of the hull, fins, and rudders.

After the resistance value of the submarine model is obtained, the coefficient of model resistance $(C T m)$ can be calculated using Eq. 4 and the coefficient of the friction model $(\mathrm{CFm})$ can be calculated using Eq. 2 based on the parameters of the mini-submarine model with scale 1:7. From the results of the resistance test of a 22meter mini-submarine model, a table can be made for the graph of the Prohaska method as shown in Table 4, while the form factor $(1+k)$ graph by using the Prohaska method from the test results is shown in Fig. 5.

From Table 4, a Prohaska graph can be made by plotting the results of the $C T m / C F m$ comparison on the $Y$-axis and the results of the $F n 4 / C F m$ comparison on the $X$-axis. And the linear line equation $y=a x+b$ is made. In Fig. 5, it is obtained the linear equation $y=25.073 x+$ 6.3818 with an $R$-squared value of 0.9402 . From this line equation then can be determined the value of form factor $(1+k)$ by substituting the value $x=0$ in the linear equation. So the $Y$ value is obtained 6.3818 . Thus the value obtained from the form factor $(1+k)$ on the minisubmarine is 6.3818 . 


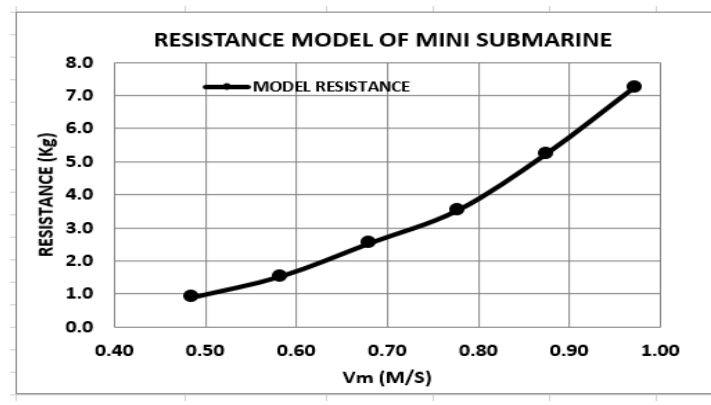

Figure 4 . The resistance of the $22 \mathrm{~m}$ mini-submarine model

Table 4. Coefficient calculations for Prohaska chart

\begin{tabular}{ccccc}
\hline $\boldsymbol{R} \boldsymbol{n}$ & $\boldsymbol{C T m}$ & $\boldsymbol{C F m}$ & $\begin{array}{c}\boldsymbol{C F m} / \\
\boldsymbol{C T m}\end{array}$ & $\begin{array}{c}\boldsymbol{F n 4 /} \\
\boldsymbol{C F m}\end{array}$ \\
\hline $1.70 \mathrm{E}+06$ & 0.468 & 0.024 & 0.0042 & 5.813 \\
$2.03 \mathrm{E}+06$ & 0.583 & 0.029 & 0.0040 & 7.127 \\
$2.37 \mathrm{E}+06$ & 0.681 & 0.035 & 0.0039 & 8.886 \\
$2.71 \mathrm{E}+06$ & 0.778 & 0.037 & 0.0038 & 9.727 \\
$3.05 \mathrm{E}+06$ & 0.875 & 0.043 & 0.0037 & 11.645 \\
$3.39 \mathrm{E}+06$ & 0.972 & 0.049 & 0.0037 & 13.323 \\
\hline
\end{tabular}

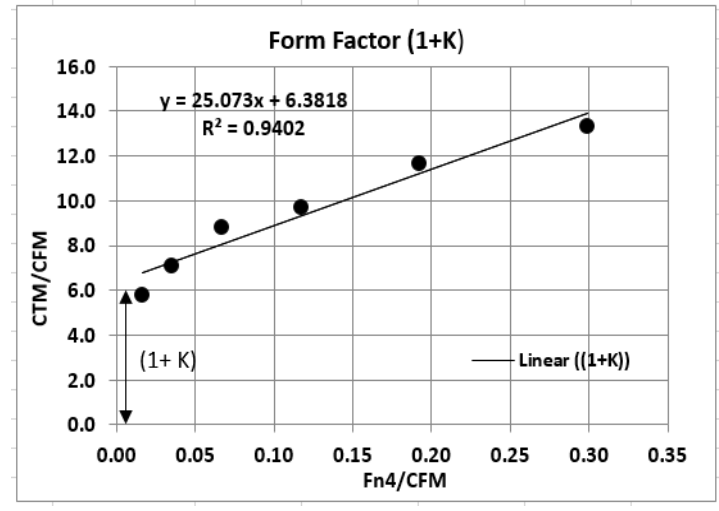

Figure 5. The form factor $(1+k)$ using Prohaska method from the test results

The difference in form factor values between minisubmarines and surface ship is much different where the value of form factors on surface vessels is 1.13 to 1.35 as shown in Table 1, while the form factor values on minisubmarines reach 6.38. However, the form factor on this mini-submarine is considered appropriate when referring to Table 5.

From Table 5, it can be ascertained that the hull shape of the 22m mini-submarine model is Parallel Middle Body Hull (PMB) because the value of the form factor produced is 6.38. Because this form factor is a fixed coefficient, then the coefficient value remains the same if the submarine is made into the full-scale form [14].

If the form factor value is known then it can be used to calculate the coefficient of resistance of minisubmarines in full scale (CTs) using equation 1 above. Next, the extrapolation process is calculated from model resistance to full-scale mini-submarine resistance because the value of submarine coefficient (CTs) has been obtained.
Table 5. Submarine form factor based on hull shape [15]

\begin{tabular}{lr}
\hline Description & \multicolumn{1}{c}{ לhull } \\
\hline Teardrop shape & 3 \\
Modern submarine shape & $4 \sim 5$ \\
PMB hull from & 6 \\
\hline
\end{tabular}

\section{Conclusion}

From the research that has been conducted, it can be seen that the difference in form factor values is quite significant between the surface ship type and the $22 \mathrm{~m}$ mini-submarines. By the form factor value of 6.38 , it can be ascertained that the shape of the submarine model is based on the Parallel Middle Body (PMB) hull concept. The hull shape of this submarine type provides advantages because the hull shape is wider when compared to the concept of the hull type of teardrop shape. But with a little area of the shape, this submarine's hull can also increase the coefficient of skin drag fiction and total drag on the mini-submarine hull.

\section{Acknowledgments}

The authors highly appreciate a research grant from the Agency for the Assessment and Application of Technology to conduct this study.

\section{References}

[1] Dhana, F. R. (2018). Analisis Alternatif Hull Form Self-Propelled Barge Untuk Meningkatkan Performa Hidrodinamika. Tesis. Fakultas Teknologi Kelautan: Institut Teknologi Sepuluh Nopember.

[2] Kusuma, Cahya. (2017). Desain Propeller Kapal Selam 29 Meter dengan Menggunakan Propeller B-Series. Jurnal Wave Volume 11 Nomor 1, Juli 2017: Hal: 1-6.

[3] Syafiul, Ahmad. dan Ridwan Utina. (2017). Analisa Pengaruh Variasi Kecepatan Terhadap Tekanan pada Model Kapal Selam dengan Menggunakan Simulasi Numerik. Jurnal Wave Volume 11 Nomor 2, Desember 2017: Hal: 17-24.

[4] Nugroho, Wibowo h. dan Ahmad Syafiul. (2015). Prediksi umur kelelahan struktur badan tekan kapal selam karena pengulangan perubahan beban hidrostatik. Jurnal MIPI (Majalah Ilmiah Pengkajian teknologi). Vol 9, No 3. BPPT. Jakarta.

[5] Aden. (2020). Analisis estimasi dan prediksi form factor berbagai bentuk lambung kapal berdasarkan data uji model dan simulasi CFD. Final Project. Department of Naval Architecture. Faculty of Marine Technology. Sepuluh Nopember Institute of Technology. Surabaya.

[6] Martin Renilson (2015), Submarine Hydrodynamics. Launceston TAS, Australia.

[7] ITTC (2008). Uncertainty Analysis in Resistance Towing Tank Tests. In: Proceeding of 25th ITTC. Fukuoka, (pp. 1-16).

[8] Larsson, L., Raven, H.C. (2010). The Principles of Naval Architecture Series Ship Resistance and Flow. New Jersey: The Society of NavalArchitects and Marine Engineers.

[9] Prohaska, C.W. (1966). A Simple Method for the Evaluation of the Form Factor and Low-Speed Wave Resistance. In: Proceedings of 11th ITTC. Society of Naval Architects of Japan, Tokyo, (pp 6566).

[10] Molland, A.F., Turnock, S.R., dan Hudson, D.A. (2011). Ship Resistance and Propulsion: PracticalEstimation of Ship Propulsive Power, Cambridge University Press, New York, USA.

[11] Edward V. Lewis. (1988) Principles of Naval Architecture Second Revision. Volume II. Resistance, Propulsion and Vibration. The Society of Naval Architects and Marine Engineers 601 Pavonia Avenue Jersey City, NJ. 
[12] Martin, R. (2015). Submarine Hydrodynamic. Springer Briefs in Applied Sciences and Technology.,

[13] Andi Jamaluddin \& Dewi Kentjanawati, (2013), Eksperimental Studies Viscous Form Factor on Resistance Catamaran Vessels, Jurnal Wave Volume. 7 Nomor 1, Juli 2013: Hal 1 -6.
[14] Renilson MR, Ranmuthugala D (2012) The effect of proximity to Free surface on the optimum length/diameter ratio for a submarine. In: First international conference on submarine technology and marine robotics (STaMR 2012), Chennai, 13-14 Jan 2012.

[15]Warren CL, Thomas MW (2000) Submarine hull form optimization case study. Naval Eng J112 (6) 